\title{
Dollarization of Liabilities in Non-tradable Goods Sector
}

\author{
By: Frédéric Chabellard
}

Working Paper No. 380

June 2001 


\title{
Dollarization of Liabilities in Non-tradable Goods Sectors
}

\author{
Frédéric Chabellard ${ }^{\star}$ \\ Université de Pau et des Pays de l'Adour, France \\ (Comments welcome)
}

\begin{abstract}
A bstract
This paper questions the motivation of dollar indebtedness by ..rms of the non-tradable good sectors in a period of exchange rate pressure. Given the structure of banks' indebtedness and protection of banks' foreign lenders, a dollar denominated loan may allow ..rms to insure (partially) against the risk of an early liquidation of their projects if they turn out to be poor. Then it is shown that under dollarization of liabilities the government may be urged to soften monetary policy to induce a real appreciation that supports the domestic banking system. Therefore, it might be constrained in its ability to enforce an ec cient regulatory policy.

J EL classi..cation: G33; G28
\end{abstract}

Keywords: Foreign currency debt; Real and nominal exchange rates; Soft budget constraints; Too many to fail; R egulatory forbearance

\footnotetext{
${ }^{a}$ A venue du Doyen Poplawski, 64000 Pau, France. Tel.: +(33)5 598075 80; fax: +(33)5 598075 90; e-mail: frederic.chabellard@univ-pau.fr.

The author thanks participants at the 2001 AF SE conference on ..nancial intermediaries, M. Laclau, D. Laborde and especially J. Le Cacheux for comments. All errors are my own.
} 
Dollarization of liabilities in the corporate sector characterizes many emerging or transition economies. It has proven to be potentially destabilizing, as for example in the recent A sian crisis. Addressing the issues raised by such a phenomenon requires ..rst to investigate ..rst the emergence of private foreign currency debt. The present paper questions intermediated dollar indebtedness by ..rms of the non-tradable goods sectors in a period of exchange rate pressure.

The setting is a simple game-theoretic model with three dates. In a small open economy we consider relationships between a bank and ..rms. The former's liabilities are made up of one unit of the tradable good, whose price at the intermediary date is random. The bank can choose to lend one unit of tradable or non-tradable good. Firms need one unit of good (whatever its nature) to start an investment project, which can be either good or poor. A poor project requires to be rolled over at the intermediary date to be completed. The liquidation policy of the bank depends, on the one hand, on the currency denomination of loans and, on the other hand, on the value of nominal and real exchange rates. A dollar loan allows banks to preserve the real value of their claims, but is riskier. However, because of the guarantee of its external debt, the bank may choose to grant dollar loans under conditions that are speci..ed. The bank's strategy depends especially on the average quality of projects in the economy: The lower the proportion of good projects in the economy, the proner the bank will be to lend tradable goods instead of non-tradable goods. As far as ..rms are concerned a dollar loan may allow them to bene.t from a higher probability of facing a soft budget constraint. Firms' preferences are determined by the average quality of projects that represents the probability of having a good project and the private bene..t the entrepreneurs extract from managing their project.

Then, the model is modi..ed to focus on banks-government relationships and analyses prudential regulation under dollarization of liabilities in non-tradable goods sectors. A cost-minimizing government is allowed to manipulate the real exchange rate, through the price of the non-tradable good. It can under particular circumstances lower the expected costs of banks rescue if rolled over poor projects fail. The negative counterpart is that it may be constrained in its ability to implement an eł cient prudential policy because of a higher probability of facing a too many to fail situation as de..ned by Mitchell (1998). 


\section{Introduction}

Private short-term foreign currency debts have played a central role in most recent emerging market crises. In East A sian countries, observers stressed the importance of short-term foreign currency outstanding debt both in corporate and banking sectors. The corporate sector borrowed in foreign currencies either directly from international investors or through domestic ..nancial intermediaries as, for example, in Indonesia; banks usually intermediate foreign capital in $\ddagger$ ows because of a cost advantage over foreign lenders in observing the output realization of domestic ..rms. Moreover, ..rms of both tradable and non-tradable goods sectors contracted dollar denominated debt. The riskiness of such a choice is more striking in the latter case, for which real estate provides a good example, since ..rms' earnings and debts are not denominated in the same currency. Firms might be very vulnerable to exchange rate depreciation. Financial intermediaries also borrowed heavily in hard foreign currencies, typically the dollar or the yen, to grant domestic or foreign currency loans to ..nance domestic activities of ..rms. The BIS (1998) reported that in 1995 and 1996 banks of ...ve A sian countries (K orea, Indonesia, Malaysia, Thailand and the Philippines) borrowed $\$ 43$ billions per year. Foreign currency debts accounted for up to thirty percent of banks liabilities. In a context of insuф cient and ineф্ cient prudential regulation, this led to high and certainly excessive investment in Asian economies. Corsetti et al., (1999, p1230-31) notice that "..nancial intermediation played a key role in channeling funds toward projects that were marginal if not outright unpro..table". Eventually, when the crisis occurred, resulting balance sheet mismatches both in corporate and banking sectors contributed to a deepening of the A sian crisis, and to a greater diф culty to manage this crisis (see e.g., BIS, 1998 or J eanne, 2000).

Despite these destabilizing exects, little inquiry has concerned the emergence of intermediated dollar denominated debt in non-tradable goods sectors so far. The BIS (1998) noticed that ..xed or quasi-..xed pegs maintained on a long period might have led economic agents to a false assessment of exchange rate risk. ${ }^{1}$ On the other hand, few analyses are based on the idea that foreign currency indebtedness could be justi..ed by private bene..ts for agents.

\footnotetext{
${ }^{1} \mathrm{M}$ oreover, this mistake could have been strengthened by an "inverse money illusion", the agents reasoning in terms on interest rates of US dollars or yen corrected by domestic infation. This occurs when a ..xed exchange rate regime is associated with high interest rate and high infation. R esidents are encouraged to borrow in foreign currency to ..nance domestic activity or domestic asset purchases, especially real estate in the A sian example (see BIS, 1998).
} 
B urnside, Eichenbaum and Rebelo (2001) point out that ..xing the exchange rate oxers free insurance to ..rms which borrow in dollar. Caballero and K rishnamurty (2000) stress the role of foreign currency liabilities as an insurance against a shortage of external resources, assumed necessary for production. International ..nancial constraints of developing countries justify the purchase of such an insurance. M oreover, they show that both domestic ..nancial system underdevelopment and limited domestic collateral of ..rms explain that ..rms systematically undervalue insurance provided by local currency debt against countrywide shocks. In a model with foreign lenders but no banks, Schneider and Tornell (2000) show that ..rms of the non-tradable goods sectors may choose a dollar denominated debt to switch a part of their expected debt burden to foreign creditors, if the realization of the real exchange rate turns out to be unfavorable. $A$ .rm that does not meet its debt burden at the expected date is liquidated. Hence, they cannot capture wide "evergreening" practices, which seem have been a general feature of banking in the East Asian experience (see e.g., Caprio and Honohan, 1999).

Caballero and K rishnamurty assume that each Ioan is fully collateralized with assets denominated in the loan denomination currency; their model allows no default on debt. Schneider and Tornell suppose the immediate liquidation of a ..rm, when it cannot repay its ..nancial obligations. On the contrary, the present paper proposes an explanation based on banks liquidation policy with respect to defaulting loans and is related to soft budget constraint theories. In this analytical framework, ..rms' creditors cannot commit not to re..nance -or to roll over- a project not completed at the expected date. K ornai (1980) introduced the concept of soft budget constraint focusing on political motivations. Dewatripont and Maskin (1995) stressed the ex-post pro..tability of a re..nanced project in the presence of irreversibilities. The soft budget constraint phenomenon can occur even if re.nancing the poor project is ex-post inec cient. In Mitchell's analysis (M itchell, 1998), ..rms' budget constraints are soften because banks gamble for resurrection or attempt to trigger a too many to fail. ${ }^{2}$

We retain the latter approach in this paper to analyze dollarization of liabilities before an exchange rate and/ or a banking crisis occurs. We develop a simple model that extends this framework in order to consider two stylized facts of banking in emerging countries. Firstly, as already mentioned, a large part of commercial banks' liabilities is denominated in hard foreign currencies. Therefore, expected or observed exchange rate variations axect banks' balance sheets

\footnotetext{
${ }^{2}$ Dewatripont and Roland (2000) or M askin and Xu (2001) provide recent surveys of soft budget constraint theories.
} 
on the liabilities side and may change their incentives. Secondly, the government, often supported by international organizations, guaranties external debt of banks, especially in order to maintain access to international capital markets. Such an insurance is typically associated with the abandonment of an exchange rate peg. Empirical evidence supports this as shown for example by Hawkins and Turner (1999) or Corsetti et al. (1999). This means that banks bene.t from a limited liability, which is here the origin of a moral hazard problem. They choose a risky asset (here they roll over a defaulting loan) with a high return if the gamble succeeds, but leave it to the government if the gamble fails.

Section 2 presents the model of bank-..rms relationship and shows that liquidation policy of banks depends on the one hand, on the currency denomination of loans and on the other hand on the value of nominal and real exchange rates. A dollar loan allows banks to preserve the real value of their claims but is riskier. However, because of the guarantee of their external debt, banks may choose to grant dollar loans under conditions that are speci..ed. Banks' strategy depends especially on the average quality of projects in the economy. As far as ..rms are concerned, a dollar loan may allow them to bene..t from a higher probability of facing a soft budget constraint. Once again, ..rms preferences are determined by the average quality of projects that represents the probability of having a good project.

In section 3, the model is modi..ed to focus on banks-government relationships and analyses prudential regulation under dollarization of liabilities in non-tradable goods sectors. T he analysis relies on the concept of too many to fail. Such a situation occurs when closing down a large number of insolvent banks is more costly than rescuing them. We show that a cost-minimizing government might manipulate the real exchange rate to lower the costs of rescue. The negative counterpart is that it might be constrained in its ability to implement an ec cient prudential policy. Section 4 presents ..nal remarks and an appendix follows.

\section{Foreign debt guarantee and soft budget constraints}

\subsection{General framework}

Consider a simple model of a small open economy. ${ }^{3}$ There are three periods $t=0 ; 1 ; 2$. The discount rate is zero. There are two perfectly divisible goods in the economy. The ..rst one is a

\footnotetext{
${ }^{3} \mathrm{~T}$ he model considers domestic currency denominated variables. U sing the tradable good as a numeraire does not axect any result derived here.
} 
non-tradable good whose related variables are denoted with subscript $\mathrm{N}$; its domestic currency price is $\mathrm{P}_{\mathrm{N}}$. The second one is an internationally tradable good ${ }^{4}$ denoted with subscript $\mathrm{T}$; its domestic currency price $p_{T}$ is a random variable which at $t=1$ takes on a range of values

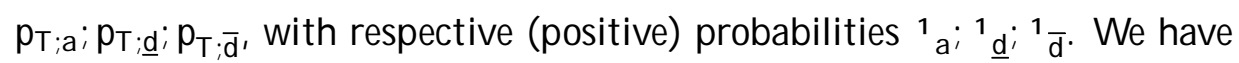

$$
{ }_{i=a ; \underline{;} ; \bar{d}}{ }_{i}=1
$$

This distribution is common knowledge. There is no change in the price of the tradable good between $t=1$ and $t=2$. Wealso assume that at $t=0, p_{T}=p_{N}$. It means that the real exchange rate, de..ned as the relative price of the tradable good in terms of the non-tradable good $\frac{p_{T}}{p_{N}}$, is equal to 1 at the beginning of the game. Then, $\mathrm{p}_{\mathrm{T} ; \mathrm{a}} ; \mathrm{p}_{\mathrm{T} ; \underline{\mathrm{d}}}$ and $\mathrm{p}_{\mathrm{T} ; \mathrm{d}}$ correspond respectively to a decrease (a nominal appreciation), a small increase (a small nominal depreciation) and a high increase (a high nominal depreciation) of $\mathrm{p}_{\mathrm{T}}$. The same analysis holds with devaluation in the case of ..xed or quasi-..xed exchange rate regime; in this case, ${ }^{1} \underline{d}$ and ${ }^{1} \bar{d}$ express the probability

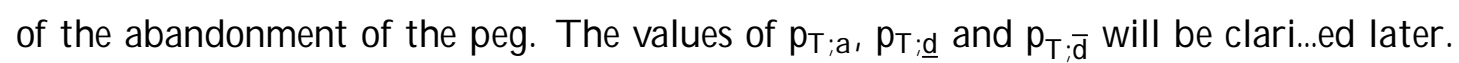

\subsubsection{The domestic productive sector}

There are $\mathrm{F}$ identical (risk neutral) entrepreneurs, with $\mathrm{F}$ normalized to 1. Each entrepreneur is endowed with an investment project, that concerns the non-tradable good. There are two types of project (we identify the quality of a project with that of its entrepreneur). It is good i.e. completed in one period with probability ${ }^{\circledR}$. Then, it yields a gross return $p_{N} Y_{N}$ where $Y_{N}$ denotes ..rm's output. The gross return of the project is not axected by the price of the tradable

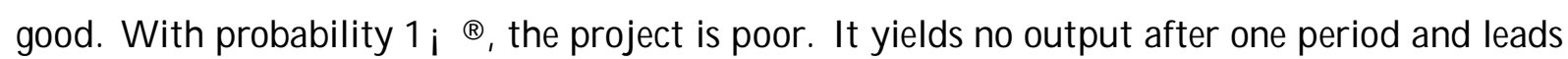
the entrepreneur to default on its loan at $t=1$. A poor project may be completed in the second period provided that the loan is rolled over. However, it yields a random production $t_{N}$ with 作 $2\left[0 ; Y_{N}\right]$. The distribution $(\circledR, 1 ; @)$ is common knowledge but an entrepreneur does not know her type at the outset of the game.

The project needs equivalently either one unit of non-tradable good or one unit of tradable good to be started. An entrepreneur has no endowment herself at period 0 . So she has to

\footnotetext{
${ }^{4} \mathrm{~T}$ he country is assumed to be price taker in the world market for importables and exportables. Therefore the terms of trade are exogenously given. Since we do not need to distinguish between exportables and importables, we can aggregate them into a composite commodity called tradable goods whose price (in dollar) is exogenously determined and supposed constant in this model.
} 
obtain ..nancing, i.e. one unit of good, from the bank. She may ask for one unit of non-tradable good (a domestic currency loan) or for one unit of tradable good (a foreign currency loan, typically a dollar denominated loan). The ..rst one imposes, at $t=1$, a repayment obligation D 2 [0; $p_{N} Y_{N}$ [. The second one imposes a repayment obligation, which depends on the value of the price of the tradable good. It may be $\mathrm{D}\left(\mathrm{p}_{\mathrm{T} ; \mathrm{a}}\right), \mathrm{D}\left(\mathrm{p}_{\mathrm{T} ; \mathrm{d}}\right)$ or $\mathrm{D}\left(\mathrm{p}_{\mathrm{T} ; \mathrm{d}}\right)$, henceforth denoted $\mathrm{D}_{\mathrm{T} ; \mathrm{a}}, \mathrm{D}_{\mathrm{T} ; \underline{d}}$ and $\mathrm{D}_{\mathrm{T} ; \mathrm{d}}$ for simplicity. Following our assumptions on tradable good prices, we have $\mathrm{D}_{\mathrm{T} ; \mathrm{a}}<\mathrm{D}_{\mathrm{N}}<\mathrm{D}_{\mathrm{T} ; \underline{\mathrm{d}}}<\mathrm{D}_{\mathrm{T} ; \mathrm{d} \text {. }}$ The entrepreneurs' objective function can be generally expressed as

$$
\underline{a}=\max f p_{N} Y_{N} ; \quad D ; 0 g+\theta
$$

An entrepreneur receives the net return of the project $p_{N} Y_{N} ; \quad D_{N}$ or $p_{N} Y_{N} i \quad D_{T ; i}$ for i $2 \stackrel{\left({ }^{\circ}\right.}{a} ; \underline{d} ; \bar{d}^{\underline{a}}$ if positive; in fact, we will assume that $p_{N} Y_{N}>D_{T ; d^{\prime}} \cdot{ }^{5}$ It means that entrepreneurs bene.t from a limited liability. In addition to that monetary pro..t, an entrepreneur has a private bene.t if she retains her position. More speci..cally, she retains her private bene..t if her project is good or if her project is poor and rolled over (then $\theta=b$; otherwise $\theta=0$ ).

\subsubsection{The bank}

The characterization of the bank borrows from Mitchell (1998). It has no initial capital. Then, the bank's liabilities can be expressed as

$$
d_{N} p_{N}+d_{T} p_{T}^{(0)}
$$

where $d_{N} p_{N}$ is the non-tradable good debt, $d_{T} p_{T}^{(0)}$ the tradable goods debt vis-à-vis external investors and $p_{T}^{(0)}$ the price of the tradable good at the outset of the game. Debts have to be repaid at the end of the game. For the sake of analytical simplicity, we assume that $d_{N}$ is zero and $d_{T}$ is equal to 1 . Then bank's liabilities are equal to $p_{T}^{(0)}$. Bank's liabilities are completely made up of an external debt that amounts to the value of one unit of tradable good. The important assumption is the guarantee of bank's external debt in tradable good. We assume that the government ${ }^{6}$ pays back foreign lenders if the bank's end of game net position is negative.

\footnotetext{
${ }^{5} \mathrm{M}$ ore speci..cally, it means that if $\mathrm{Y}_{\mathrm{N}}$ is realised, it allows an entrepreneur to pay its loan back. This assumption appears realistic since we investigate periods of exchange rate pressure and not the crisis itself. When the A sian crisis occured, devaluation of A sian currency were generally very large (for example, 75\% in Indonesia); in such a case, even an entrepreneur endowed with a good project is likely to be driven into insolvency.

${ }^{6} \mathrm{~T}$ he government is a passive player in this section.
} 
As far as bank's assets are concerned, the bank can choose to lend either one unit of nontradable good or one unit of tradable good (we implicitly assume that the bank can exchange one unit of tradable good for one unit of non-tradable good without incurring costs at $t=0$ ). It is also assumed that the bank charges each loan with the same real interest rate $r$ : Interest rates issues are obviously important issues to understand borrowing and lending choice respectively of ..rms and banks. However, we focus here on another aspect of the problem. Let us consider each loan denomination in turn.

Firstly, the bank chooses to grant a non-tradable good loan. If the project turns out to be good, the loan is completely repaid. The return is $D_{N}$. When the bank faces default at intermediary period (i.e. the project is poor), it can choose either a tough liquidation policy or a soft liquidation policy. We will equivalently refer to a tough liquidation policy or imposing a hard budget constraint $(\mathrm{HBC})$ and to a soft liquidation policy or imposing a soft budget constraint (SBC).

In the case of a tough policy, the bank receives a liquidation value $L$ (with $L>0$ ) which expresses the value of an entrepreneur's collateral. A s IMF noticed concerning ..nancial intermediation in East Asia, banks lending practices have relied on collateral rather than credit assessment and cash- $¥$ ow analysis. Yet, on the one hand, collaterals were generally overvalued and on the other hand, diф culties in seizing and realizing a collateral reduce its value. A soft liquidation policy means "evergreening" the loan; it is rolled over without being reclassi..ed (hence, the bank makes no provision) and without any consideration of project restructuring. Let suppose that there is no change in the nature, non-tradable or tradable, of the borrowed good. In that case, the project will succeed with probability q that can be written as $q_{N}=\operatorname{Prf} p_{N} p_{N}$ i $p_{N}(1+r), 0 g$ or equivalently $q_{N}=$ Prf $e_{N} i(1+r), \quad 0 g .^{7}$ The price of the non-tradable good does not axect the probability of repayment of a rolled over loan. The expected return of the loan is $q_{N} D_{N}$. Let us assume that $D_{N}>L>q_{N} D_{N}$. Furthermore, when a rolled over poor project fails that is the realized output does not allow the ..rm to repay its debt, whatever the nature of the borrowed good, it yields for the bank at $t=2$, an end-of-game liquidation value I normalized to zero. Hence, the soft budget constraint phenomenon arises because a poor project whose liquidation value is greater than its continuation value is not terminated.

Secondly, the bank chooses to grant a tradable good loan. The expected repayment depends

\footnotetext{
${ }^{7}$ Ex-post, a poor project that succeeds may be seen as an illiquid one whereas a poor project that fails may be seen as an insolvent one.
} 
on the price of the tradable good. For example, an increase (a nominal depreciation) may have two exects. The ..rst one is an increase in the claim value. As stated before, the debt has in such a case, two possible outcomes $\mathrm{D}_{\mathrm{T} ; \underline{\mathrm{d}}}$ and $\mathrm{D}_{\mathrm{T} ; \overline{\mathrm{d}}}$. Depreciation means symmetrically an increase of entrepreneurs' debt burden while the value of their assets remains unchanged. Therefore we assume that the probability of repayment of a rolled over loan is decreasing in the value of the tradable good price. ${ }^{8}$ It is worth noting that the probability of repayment can be expressed as $\mathrm{q}_{\mathrm{T} ; \mathrm{i}}=\operatorname{Prf}_{\mathrm{N}} \boldsymbol{P}_{\mathrm{N}}$ i $\mathrm{p}_{\mathrm{T} ; \mathrm{i}}(1+\mathrm{r})$, og or $\mathrm{q}_{\mathrm{r} ; \mathrm{i}}=\operatorname{Prf} \varphi_{\mathrm{N}} \mathrm{i} \frac{\mathrm{p}_{\mathrm{T} ; \mathrm{i}}}{\mathrm{p}_{\mathrm{N}}}(1+\mathrm{r})$, Og. The ability of the ..rm to repay its loan depends more on the real exchange rate $\frac{p_{T}}{p_{N}}$ than on the price of the tradable good. The lower the real exchange rate, the higher the probability of repayment. In this version of the model, since $p_{N}$ is given, both the nominal and the real exchange rates change in the same way. This second exect is captured by the following assumption: $q_{N}>q_{r ; d}>q_{\pi ; \bar{d}}$. As previously, we assume that $D_{T ; i}>L>q_{T ; i} D_{T ; i}$ for each value of $i$, that is liquidation is the ec cient ex-post policy.

\subsubsection{The timing of the game}

The timing of the game is as follows. At the outset of the game $(t=0)$, entrepreneurs choose to apply for a non-tradable good loan or for a tradable good loan. Then, the bank decides to grant non-tradable or tradable good loans. Only after contracting with the bank, entrepreneurs uncover their types. At the intermediary period $(t=1)$, return of the projects are observed. The bank also observes the value of the tradable good price. Then, it chooses action with respect to poor projects. At the end of the game $(t=2)$, the return of rolled over projects are observed and the bank is bailed out by the government if necessary. The game is of complete information and is solved by backward induction.

\footnotetext{
${ }^{8} \mathrm{G}$ enerally, a decrease in banks expected assets, following a strong domestic currency depreciation, results from the prospect of a bankruptcy wave in the productive sector especially due to slackening of economic growth, high interest rates and a cut in bank intermediation. Regarding the latter point, Berglöf and Roland (1997) showed that soft budget constraints can coexist with credit crunches.
} 


\subsection{Gambling banks and tradable goods loans}

We start with the characterization of the bank's strategy. The bank is assumed to be risk neutral; it will choose the one which maximizes its expected pro..t. ${ }^{9}$ Since the bank's liabilities come due at the end of the game, its two-period earnings minus liabilities determine its solvency. We consider both possible strategies in turn assuming, on the one hand, that ..nancing the $F$ projects is ex-ante pro.table for the bank and on the other hand, that ${ }^{\circledR D}<p_{\text {T; }} 8$ i 2 fa; $\underline{d}$; $\overline{d g}$. Returns on good projects are not high enough to permit the bank to repay its debt.

First, the bank may choose to grant non-tradable good loans. The expected return of a

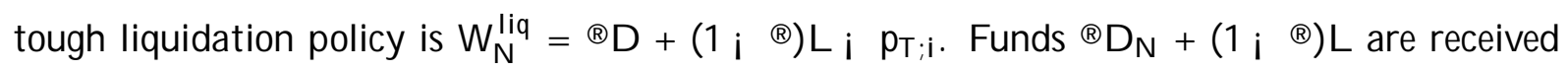
at $t=1$ and invested in a safe asset whose return is normalized to zero. With respect to a soft liquidation policy, because foreign debt guarantee provides a limited liability, the bank expected return is $W_{N}^{\text {roll }}=q_{N}\left(D_{N} i \quad p_{T ; i}\right)$. The incentive to gamble for resurrection is de..ned by $\pitchfork W_{N}=W_{N}^{\text {roll }} i W_{N}^{\text {liq. }}$ Hence,

$$
\phi W_{N}=(1 ; \quad \mathbb{R})\left(D_{N} \text { i } L\right) ;\left(1 ; \quad q_{N}\right)\left(D_{N} \text { i } p_{T ; i}\right)
$$

Clearly, this expression increases with the price of the tradable good. ${ }^{10}$ The higher the tradable good price, the higher entrepreneurs' probability of facing a soft budget constraint. The bene..t of a soft liquidation policy results from the fact that bank's debt is only repaid with probability q. An increase in the price of the tradable good strengthens the bias towards a soft liquidation strategy resulting from the dixerence between the expected repayment of bank's debt and its face value when the bank gambles for resurrection. Conversely, a decrease in the price of the tradable good leads to a tougher liquidation policy. More precisely, the bank will choose a soft liquidation policy if

$$
P_{T}, D_{N} \text { i } \frac{(1 ; \quad \&)\left(D_{N} i L\right)}{1 ; q_{N}}
$$

We assume that $\mathrm{p}_{\mathrm{T} ; \overline{\mathrm{d}}}$ is de..ned by this condition and that $\mathrm{p}_{\mathrm{T} ; \mathrm{d}}$ is not high enough for bank to become insolvent if it chooses a tough liquidation policy. Thus, the expected return (denoted

\footnotetext{
${ }^{9}$ Institutional advantages may have biased banks' loans toward foreign currency loan. For example, the P hilippines experienced a signi..cant growth in foreign currency intermediation before the crisis occurs in part because of full tax-exemption (IMF, 1999).

${ }^{10} \mathrm{U}$ nsurprinsgly, the derivative of $₫ W_{N}$ with respect to the liquidation value $L$ is negative. $A$ high liquidation value raises the opportuniy cost of rolling over poor projects. The same remark holds when the banks grants a tradable good loan.
} 
$E\left(W_{N}\right)$ ) of a bank, which chooses to grant non-tradable good loans, is

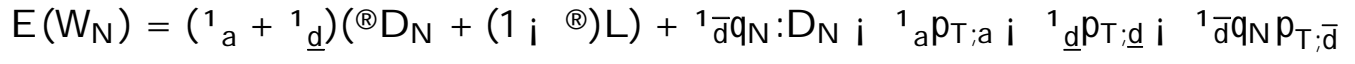

Then, the bank may choose to grant tradable good loans. As noted before, we have to consider the consequence of tradable good's price variations both on the value of the ..rm's debt and on the probability of repayment of a rolled over loan. Remember that the bank knows the ..nal price of the tradable good. The return associated with each strategy may be written as a general rule as in the ..rst case. However, repayment and probability of success depend on the tradable good price. So the incentive to soften the entrepreneurs' budget constraints $\left(\$ \mathrm{~W}_{\mathrm{T}}=\mathrm{W}_{\mathrm{T}}^{\text {roll }} \mathrm{i} \mathrm{W}_{\mathrm{T}}^{\text {liq }}\right)$ can be written as

$$
\$ W_{T}=(1 ; \quad \mathbb{R})\left(D_{T ; i} \text { i } L\right) ;\left(1 ; \quad q_{T ; i}\right)\left(D_{T ; i} \text { i } \quad p_{T ; i}\right)
$$

where $\mathrm{W}_{\mathrm{T}}^{\text {roll }} ; \mathrm{W}_{\mathrm{T}}^{\text {liq }}$ denote respectively the payo of a strategy of soft or tough liquidation policy. We now have to establish the consequence of a tradable good price variation on the incentive to enforce a soft liquidation policy. It means to compute the derivative of the incentive to gamble with respect to the price of the tradable good. From equation (6), one obtains

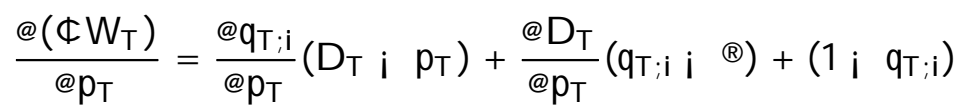

An increase in the price of the tradable good will induce bank to implement a soft liquidation policy if this expression is positive. The ..rst term is negative ( $\frac{\varrho_{\mathrm{Q}} ; \mathrm{i}}{\mathrm{Q}_{\mathrm{T}}}<0$ for $\mathrm{p}_{\mathrm{N}}$ given and $\left.D_{T}>p_{T}\right)$. It represents the negative exect on bank's incentive to gamble due to the increase in the probability of failure (because of the depreciation) of a poor rolled over project. The sign of the second term depends on the sign of $\left(q_{T ; i} i \mathbb{R}\right)$. If $q_{T ; i}>\mathbb{R}$, this term indicates the strengthening of the incentives to gamble related to the rise of the value of the potentially recoverable claim. On the other hand, if $\mathrm{q}_{\mathrm{T} ; \mathrm{i}}<{ }^{\circledR}$ the bank may choose a tough liquidation policy. The last term stands for the debt exect on the incentive to gamble. When it chooses a soft liquidation policy, the expected value of bank's debt is lower than its face value.

We assume that the overall expression is positive. Increase in the price of the tradable good urges the bank to adopt a soft liquidation policy. The bank's focus on the value of the claim, rather than the probability of repayment, can justify this assumption. A ctually, observers stressed that in the case of A sian crisis, banks seem not to have taken into accounts the negative relationship between the probability of repayment and the exchange-rate value, when lending in 
hard foreign currency (in our setting, it means that $\frac{\varrho_{4} ; i}{\mathfrak{Q}_{T}}$ is equal or close to zero). They might have believed they just had to balance their own foreign currency debt with foreign currency loans to domestic ..rms or households to ..nance domestic activities (BIS, (1998); Caprio and Honohan, (1999)). Finally, devaluation of Asian currencies has made the exchange rate risk reappear as credit risk.

Let de.ne $\mathrm{p}_{\mathrm{T} ; \mathrm{a}}$ (with $\mathrm{p}_{\mathrm{T} ; \mathrm{a}}<\mathrm{p}_{\mathrm{T}}$ ) as a tradable good price such that the bank implements a tough liquidation policy whatever the denomination currency of the loan. Then, de..ne $p_{T ; \underline{d}}$ (with $\mathrm{p}_{\mathrm{T}}<\mathrm{p}_{\mathrm{T} ; \mathrm{d} \text { ) }}$ the tradable good price which corresponds to an increase in $\mathrm{p}_{\mathrm{T}}$ so high as to lead the bank to choose a soft liquidation policy when granting a tradable good loan. We have to check whether $\mathrm{p}_{\mathrm{T} ; \underline{\mathrm{d}}}<\mathrm{p}_{\mathrm{T} ; \mathrm{d} \text {. }}$ The following claim states this.

Claim 1 From the de..nitions of $\mathrm{p}_{\mathrm{T} ; \underline{\mathrm{d}}}$ and $\mathrm{p}_{\mathrm{T} ; \overline{\mathrm{d}}}$, we have $\mathrm{p}_{\mathrm{T} ; \underline{\mathrm{d}}}<\mathrm{p}_{\mathrm{T} ; \overline{\mathrm{d}}}$ if

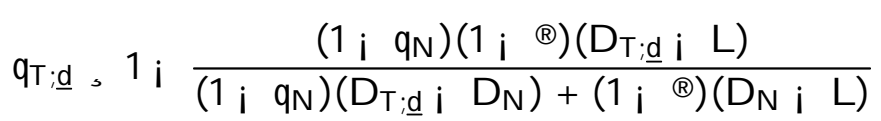

From now on, we assume that the probability of repayment $\mathrm{q}_{\mathrm{T} ; \mathrm{d}}$ satis..es this condition. It means that if $q_{r ; \underline{d}}$ is high enough, the necessary increase in the price of the tradable good to lead the bank to soften entrepreneurs' budget constraints is lower when the bank grants a tradable good loan.

Therefore we are now able to establish the strategy of the bank when it grants a dollar loan. It will implement a tough liquidation policy for $\mathrm{p}_{\mathrm{T}}=\mathrm{p}_{\mathrm{T} ; \mathrm{a}}$ and a soft liquidation policy otherwise. Its expected payox is thus $\mathbb{R}_{\mathrm{T} ; \mathrm{a}}+\left(1_{\mathrm{i}} \circledast \mathbb{L}_{\mathrm{L}}\right.$ i $\mathrm{p}_{\mathrm{T} ; \mathrm{a}}$ if $\mathrm{p}_{\mathrm{T}}=\mathrm{p}_{\mathrm{T} ; \mathrm{a}}$, and $\mathrm{q}_{\mathrm{T} ; \mathrm{i}}\left(\mathrm{D}_{\mathrm{T} ; \mathrm{i}} \mathrm{i} \mathrm{p}_{\mathrm{T} ; \mathrm{i}}\right)$ for $\mathrm{i}=\underline{\mathrm{d} ;} \overline{\mathrm{d}}$. We have

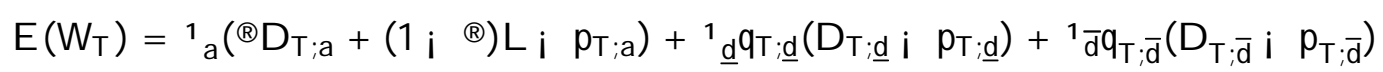

The bank is going to accept a tradable good loan if its expected payou is higher than the expected payox associated with a non-tradable good loan. That is if $E\left(W_{T}\right), E\left(W_{N}\right)$. Rewriting this condition, we have the following proposition.

Proposition 2 If equation (8) is satis..ed, then the bank chooses to grant a tradable good loan if

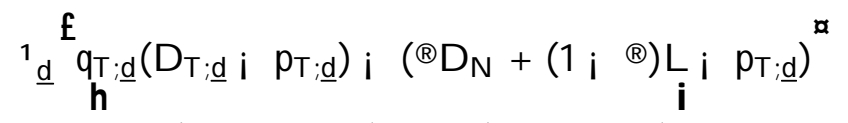

$$
\begin{aligned}
& +{ }^{1} \bar{d} \quad q_{T ; \bar{d}}\left(D_{T ; \bar{d}} \text { i } \quad p_{T ; \bar{d}}\right) \text { i } \quad q_{N}\left(D_{N} \text { i } \quad p_{T ; \bar{d}}\right) \\
& \text {, } \quad{ }_{a} \otimes\left(D_{N} \text { i } D_{T ; a}\right)
\end{aligned}
$$


The ..rst term indicates the expected earnings of a soft liquidation policy in the case of a low depreciation ( $\mathrm{p}_{\mathrm{T}}=\mathrm{p}_{\mathrm{T} ; \underline{\mathrm{d}}}$ ). The second term represents potential earnings resulting from a soft liquidation policy in the case of a strong depreciation $\left(p_{\mathrm{T}}=\mathrm{p}_{\mathrm{T} ; \overline{\mathrm{d}}}\right.$ ). In fact, the sign of this term is diф cult to assess because $D_{T ; \bar{d}} i \quad p_{T ; \bar{d}}>D_{N} i \quad p_{T ; \bar{d}}$ and $q_{T ; \bar{d}}<q_{N}$. The third term represents the loss of pro..t associated to good projects when there is an appreciation in the price of the tradable good. From basic comparative static, we derive the following corollary.

Corollary 3 The lower the proportion of good projects in the economy, the proner the bank will be to lend tradable goods instead of non-tradable goods.

Proof. The proof is straightforward. Ones compute the derivative of equation (10) with

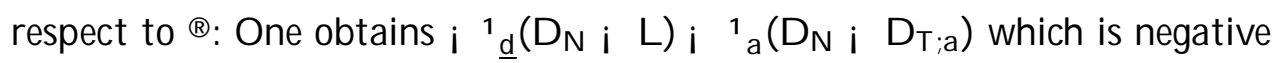

The guarantee of its external debt provides the bank with an implicit subsidy, which increases with credit risk. Then, if the former is high, it leads banks to take on more risk through tradable good loans. We now question ..rms' possibility to take advantage of this.

\subsection{Why do entrepreneurs borrow the tradable good?}

The model allows no bargaining power to the ..rm on the choice of the nature of the borrowed good. So this section aims at characterizing entrepreneurs preferences. ${ }^{11}$ The important point here is that entrepreneurs do not know their type when they ask the bank for a non-tradable or a tradable good loan. An entrepreneur only knows the distribution ( $\circledR_{;} ; \mathrm{i} \circledast$ ) of good and poor projects in the economy. Consider the two possibilities in turn. Borrowing a nontradable good is the ..rst possibility. If her project is good, an entrepreneur's expected payox is ${ }^{a}{ }_{N}=\left(p_{N} Y_{N} i \quad D_{N}\right)+b 8 p_{T} 2 f p_{T ; a} ; p_{T ;} ; p_{T ;} g$. Considering the structure of its liabilities, the bank will implement a soft liquidation policy only if $\mathrm{p}_{\mathrm{T}}=\mathrm{p}_{\mathrm{T} ; \overline{\mathrm{d}}}$, which may be the case with probability ${ }^{1} \bar{d}$. If her project is poor, her expected payox is ${ }^{1} \bar{d}\left(q_{N}\left(p_{N} Y_{N} ; D_{N}\right)+b\right)$. Thus, her total expected payox is

$$
\left.E\left(\underline{a}_{N}\right)=\varangle\left(p_{N} Y_{N} ; \quad D_{N}\right)+b\right)+(1 ; \quad \circledast)^{1} \bar{d}\left(q_{N}\left(p_{N} Y_{N} ; \quad D_{N}\right)+b\right)
$$

The alternative is a tradable good loan. If her project is good, her expected payox is $\left(p_{N} Y_{N}\right.$ i $\left.\mathrm{D}_{\mathrm{T} ; \mathrm{i}}\right)+$ bwith i $2 \mathrm{f} 1 ; 2 ; 3 \mathrm{~g}$. If her project is poor, her expected payox is zero if $\mathrm{p}_{\mathrm{T}}=\mathrm{p}_{\mathrm{T} ; \mathrm{a}}$ because

\footnotetext{
${ }^{11}$ One should also have considered that ..rms bene..t from bargaining power (considering for example large capital inłows and competitive pressure on banks in East A sia). In such a case, the ...nal characterization of the equilibrium will change but the analyzis of ..rms' strategies is altered, what is our point.
} 
she faces a hard budget constraint, and $q_{T ; i}\left(p_{N} Y_{N} ; \quad D_{T ; i}\right)+b$ if $p_{T}=p_{T ; i}$ for $i=\underline{d} ; \bar{d}$, because she has a soft budget constraint. Thus, an entrepreneur's total expected payox is

$$
\begin{aligned}
E\left(\underline{a}_{T}\right)= & \mathbb{\&}\left(p_{N} Y_{N} i^{1}{ }_{a} D_{T ; a} i^{1}{ }_{\underline{d}} D_{T ; \underline{d}} i^{1}{ }_{d} D_{T ; \bar{d}}+b\right) \\
& +(1 ; \quad \mathbb{R})\left({ }^{1}{ }_{\underline{d}} q_{T ; \underline{d}}\left(p_{N} Y_{N} ; \quad D_{T ; \underline{d}}\right)+{ }^{1} \bar{d} q_{T ; \bar{d}}\left(p_{N} Y_{N} ; \quad D_{T ; \bar{d}}\right)+\left({ }^{1} \underline{d}+{ }^{1} \bar{d}\right) b\right)
\end{aligned}
$$

Entrepreneurs will choose a tradable good debt if $E\left(\underline{a}_{T}\right), E\left(\underline{a}_{N}\right)$. Consequently, we have the following proposition.

Proposition 4 Entrepreneurs will ask for tradable good loans if

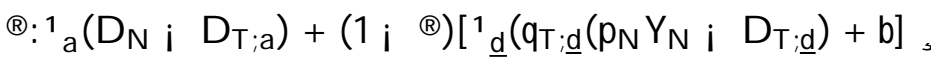

$$
\begin{aligned}
& \left.\mathbb{\otimes}_{\underline{1}}^{1}{ }_{\underline{d}}\left(D_{T ; \underline{d}} \mathrm{i} \quad D_{N}\right)+{ }^{1} \bar{d}\left(D_{T ; \bar{d}} i \quad D_{N}\right)\right] \\
& +(1 ; \quad \mathbb{Q})^{1} \bar{d}\left[q_{N}\left(p_{N} Y_{N} ; \quad D_{N}\right) ; \quad q_{T ; \bar{d}}\left(p_{N} Y_{N} ; \quad D_{T ; \bar{d}}\right)\right]
\end{aligned}
$$

Recall that a decrease in the price of the tradable good leads the bank to harden the ..rm's budget constraint whatever good is the loan denominated. Then, the ..rst term of left-hand side represents the pro..t related to tradable good denominated debt if the project is good and in the same time, the price of the tradable good decreases. It expresses the cut in ..rms' debt. The second term indicates the payox due to the distortion of the bank's balance sheet which consequence is that a lower price of the tradable good allows the entrepreneur to have a soft budget constraint. The probability of facing a soft budget constraint is now ${ }^{1} \underline{d}+{ }^{1} \bar{d}$. It means that she retains at least her private bene.t.

The right hand side of (13) only concerns monetary costs. The ..rst term stands for the loss of pro..t resulting from an increase in the tradable good price if the project is good. Finally, the second term may express the monetary loss associated to a poor project if there is a high price of the tradable good ( $p_{\mathrm{T}}=\mathrm{p}_{\mathrm{T} ; \mathrm{q}}$ ), but the ..rm's manager retains her non-monetary bene..t $\mathrm{b}$ Hence, the right hand side of (13) stands for the monetary cost of a better -partial- insurance against early liquidation of a poor project. Consequently, we can establish the following.

Corollary 5 If the private non-monetary bene..t of entrepreneurs is high enough, i.e.

$$
\begin{aligned}
& b, \quad B={\frac{1}{1}{ }^{1} \underline{d}}^{d} q_{N}\left(p_{N} Y_{N} \text { i } D_{N}\right) ; \quad q_{T ; d}\left(p_{N} Y_{N} ; \quad D_{T ; \bar{d}}\right)^{i}
\end{aligned}
$$

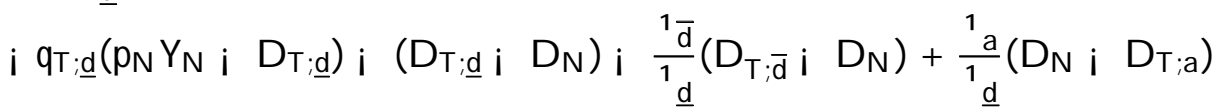


Then the higher the proportion of poor projects in the economy, the proner entrepreneurs will be to borrow tradable goods.

Proof. The proof is straightforward. One computes the derivative of equation (13) with respect to $\AA$ One obtains

$$
\begin{aligned}
& i^{1}{ }_{\underline{d}}{ }_{h}^{f} q_{T ;}\left(p_{N} Y_{N} \text { i } D_{T ; \underline{d}}\right)+b^{b d} \\
& i^{1} \bar{d} \quad q_{N}\left(p_{N} Y_{N} \text { i } D_{N}\right) \text { i } \quad q_{T ; \bar{d}}\left(p_{N} Y_{N} \text { i } D_{T ; \bar{d}}\right) \\
& +{ }^{1}{ }_{a}\left(D_{N} \text { i } D_{T ; a}\right) \text { i }{ }^{1}{ }_{\underline{d}}\left(D_{T ; \underline{d}} i \quad D_{N}\right) \text { i }{ }^{1} \bar{d}\left(D_{T ; \bar{d}} \text { i } D_{N}\right)
\end{aligned}
$$

W hich is negative for the value presented in equation (14)

This result appears consistent with Schneider and Tornell's analysis (Schneider and Tornell, 2000, p21). They found, in a dixerent setting, that as far as ..rms are concerned, "undertaking risky plans goes hand in hand with a preference for debt denominated in tradables".

Finally, it remains to precise the nature of the loan. It is possible to determine from proposition 1 and 2 cut-ox levels of $\AA$, the probability that a project be good. Denote $\mathbb{B}^{b}$ the cut-o levels respectively for the bank and entrepreneurs. If $®$. $\mathbb{B}^{b}$ and $\AA$. grants the tradable good loan, entrepreneurs applied for. The realization of the tradable good price and eventually of a rolled over project determines payoms. If $\AA>\mathbb{B}^{b}$ and $\AA$. $@$, then entrepreneurs would like to ask for a tradable good loan but the bank would turn down. It just would be willing to grant a non-tradable good loan. A ssumptions on entrepreneurs' private bene.t ensure that the project is undertaken since $E\left(\underline{a}_{N}\right)$ is positive while not undertaking the project yields a payo equal to zero. If $\AA$. $\circledast^{b}$ and $\AA>$, the issue is quite unusual. Entrepreneurs would prefer to ask for a non-tradable good loan. However the bank would only accept to grant a tradable good loan. ${ }^{12}$ At last, if ${ }^{\circledR}>\mathfrak{B}^{b}$ and $®>\mathbb{B}$, entrepreneurs apply for a non-tradable good loan and the bank accepts.

\section{Prudential policy under dollarization of liabilities}

Two main reasons explain excessive risk taking that occurred after the ..nancial liberalization in East A sia (Mishkin, 1999). The ..rst one was the lack of banks' managers of the expertise to

\footnotetext{
${ }^{12}$ Allowing the bargaining power to ..rms will obviously lead to opposite issues (in terms of the borrowed good) when the two parties have dixerent preferences on the nature of the loan.
} 
manage risk appropriately. The second ones was the inadequacy of the regulatory/supervisory policy. Together with depositors and foreign lenders protection, it generated moral hazard as for example described in the preceding section. Then, this section will discuss the capacity of the government to implement el cient regulatory and supervisory policies when ..rms in the non-tradable good sector borrow tradable goods. The discussion of regulatory and supervisory policies under dollarization of liabilities relies on Mitchell's analysis (Mitchell, 1998) who introduced the concept of too many to fail to account for large levels of creditor passivity with respect to defaulting loans in transition countries.

Let consider a sketch of Mitchell's model ${ }^{13}$. Banks and the government interact in a twostage game. The latter aims at cutting the costs resulting from the existence of non-performing loans under the constraint that foreign creditors be repaid at the end of the game. It is assumed to be cost-minimizing as in Mailath and Mester (1994). Payout to foreign lenders and costs of closing the banks constitute these costs.

Consider the preceding model with banks granting tradable good loans. Ex-ante i.e. at $t=0$,

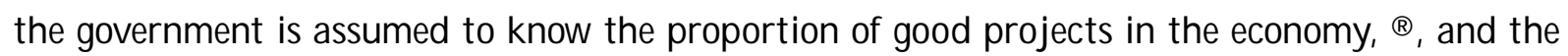
number $m$ of banks with poor projects in their portfolio (the share is $1 \mathrm{i} \circledast$ ). Furthermore, the government has ..xed a high monitoring capacity, incurring a ..x cost $K$. At $t=1$, after banks have chosen their policy, it is able to identify all banks which have implemented a soft liquidation policy with respect to defaulting loans. Then, it has to choose the ex-post policy it will implement. At $t=2$, poor projects are realized and the government repay foreign lenders if necessary. Since there are more changes in prices than in the preceding sections, we introduce superscripts when necessary to denote the date of realization.

The ..rst ex-post policy may be "closure". Banks having chosen a soft liquidation policy are closed down, poor projects are forced into bankruptcy (allowing the government to recover liquidation value of these projects) and banks' payox is zero. The government entails both direct costs (administrative costs) and indirect costs due to disruptions in the domestic ..nancial system. As in Mitchell's model, the total cost, denoted $c(m)$ is assumed to be convex in the number of closed banks. "Neutral forbearance" is the alternative policy. It means recapitalizing banks if poor rolled over projects fails and whatever the issue of the projects leaving banks

\footnotetext{
${ }^{13} \mathrm{We}$ simply discuss here the possibility of occurrence of a too many to fail situation. The demonstration of consequences on monitoring capacity of the government requires a more formal model. Since it is very close to Mitchell, we leave it in the appendix.
} 
open. The recapitalization is such that the ..nal wealth of banks is zero. Therefore the expected cost is $\mathrm{mR}^{\mathrm{min}}$ where $\mathrm{R}^{\mathrm{min}}$ denotes the expected cost of recapitalization per banks, $\mathrm{R}^{\mathrm{min}}=$ $\mathrm{m}^{\mathrm{i}} 1 \mathrm{i} \mathrm{q}^{(2)}{ }^{\mathrm{C}^{\mathrm{h}}} \mathrm{p}_{\mathrm{T}}^{(2)} \mathrm{i} \mathbb{R D}_{\mathrm{T}}^{(2)}$ and the expected payox of banks is positive.

A too many to fail occurs if closing down a large number of ..nancially distressed banks is more costly than recapitalizing them, that is if

$$
c(m), m^{3} 1 ; \quad q^{(2)}{ }^{\prime} p_{T}^{(2)} i \mathbb{B D}_{T}^{(2)}{ }^{i}
$$

M itchell shows that in such a case, an ex-ante tough prudential policy is not an issue because subgame perfection would be violated. The prudential policy is soften through weaker monitoring capacity ex-ante or through ex-post recapitalization.

To account for the evolution of exchange rates in East A sian countries before the crises occurred, that is a trend of slight nominal depreciation (sometimes owing to a crawling peg arrangement) and real appreciation (see e.g. IMF, 1999, ..g 3, p 16), we now allow the government to manipulate the non-tradable good price after having observed both the price of the tradable good and the behavior of banks. Let assume that the price of the non-tradable good does not change between $t=0$ and $t=1$ and that the end-of-game non-tradable good price may be either $p_{\underline{N}}$ or $p_{\bar{N}}$ with $p_{\underline{N}}<p_{\bar{N}}$. Y et, manipulating the non-tradable good price may now alter the price of the tradable good through a rise of the nominal exchange rate. Hence, it is supposed that

$$
\left.p_{T}^{(2)}=p_{T}^{(1)}+\# p_{N}^{(2)} i p_{N}^{(1)}\right)
$$

where $0 \cdot \pm^{14}$ Moreover, we assume that $\pm \cdot \overline{ \pm}^{\prime} \frac{p_{\mathrm{T}}^{(1)}}{p_{N}^{(1)}}$. This assumption ensures that if the realization of the price of the tradable good consists in a nominal depreciation high enough to induce banks to roll over defaulting loans at the intermediate date $\left(p_{\mathrm{T}}^{(1)}, p_{\mathrm{T} ; \mathrm{d}}\right)$, it can go with a real appreciation at the end of the game.

We ..rst have to check wether an increase in $p_{\mathrm{N}}$ undermines banks' incentives to roll over poor projects. It can be written as

$$
\phi W_{T}=(1 ; \quad \&)\left(D_{T ; i}^{(2)} i \quad L\right) ;\left(1 ; \quad q_{T ; i}^{(2)}\right)\left(D_{T ; i}^{(2)} i \quad p_{T ; i}^{(2)}\right)
$$

\footnotetext{
${ }^{14} \mathrm{~T}$ he parameter \pm is a synthetic one that incorporates the weight of non-tradable goods in the general prices index.
} 
The derivative with respect to the price of the non-tradable good is

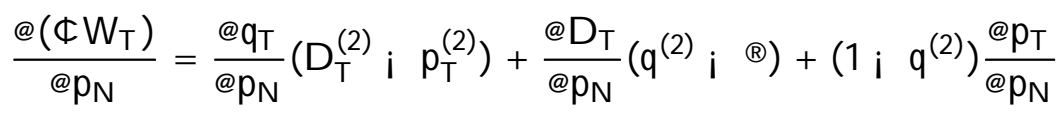

An increase in $p_{N}$ axects the probability $q^{(2)}$ of repayment of a poor rolled over project through a real appreciation; $q_{T}^{(2)}$ is increasing in $p_{N}$ because it is assumed that $\pm< \pm$ Following the preceding assumptions, the price of the tradable good $p_{T}^{(2)}$ is also increasing in $p_{N}$. It is the same for ...rms' debt in tradable good $D_{T}^{(2)}$.

A rise of $p_{N}$ may urge banks with non performing tradable good loans in their portfolio to roll over them because the probability of repayment of a rolled over project increases following the real exchange rate appreciation $\left(\frac{\varliminf_{T}}{\mathfrak{Q}_{N}}\left(D_{T}^{(2)} \mathrm{i} \mathrm{p}_{\mathrm{T}}^{(2)}\right)>0\right)$ and the value of banks' external debt rises following the induced nominal depreciation $\left(\left(1_{i} q^{(2)}\right) \frac{\mathbb{Q}_{T}}{\mathbb{Q}_{N}}>0\right.$; recall that if a bank chooses to roll over defaulting loans, the expected value of its debt is lower than its face value). Furthermore, the domestic currency return of a rolled over project rises with nominal depreciation. It will urge banks to roll over poor projects if the probability of an end of game success is high enough with respect to the proportion of good projects $\AA$ T his condition is directly linked to the importance of real appreciation due to monetary softening, therefore related to \pm The overall expression is non-negative, if one of these condition is satis..ed: $q_{T}^{(2)}$, ®or, otherwise, $\frac{@_{q}}{\Phi_{N}}\left(D_{T}^{(2)} i p_{T}^{(2)}\right)+\left(1_{i}\right.$ $\left.q_{T}^{(2)}\right) \frac{\mathbb{Q}_{T}}{\mathfrak{G} \mathbb{p}_{N}}$, $\frac{\mathbb{G}_{T}}{\mathbb{Q}_{N}}\left(\Re_{i} q_{T}^{(2)}\right)$. We assume that one of these condition is satis..ed, that is monetary softening does not de-incite banks to roll over defaulting loans.

Following our assumptions, if the government chooses to close banks, it can recover the value of their external debt by forcing debtors into bankruptcy. Then, increasing the non-tradable good price is not an issue. So, we focus on the consequences on the costs associated to forbearance. If $\pm=\mp$ any increase in the price of the non-tradable good induces a nominal depreciation so that there are no change in the real exchange rate de..ned as $\frac{\mathrm{p}_{T}}{\mathrm{p}_{\mathrm{N}}}$. It means no alteration in the probability of success of rolled over poor projects, $q_{T}$, but there is a mechanical increase in the domestic currency value of banks' external debt. Therefore, increasing $\mathrm{p}_{\mathrm{N}}$ is a dominated strategy. If $\pm=0$, the rise of $p_{N}$ does not alter the nominal exchange rate; on the other hand, there is a real appreciation that leads to an increase in $q_{r}$. Therefore, the expected costs of a strategy of forbearance decrease.

From the preceding discussion, it results that there exists a cut-o level of $\pm 2 \stackrel{f}{\mp} 0 ; \pm^{\not}$, denoted $\stackrel{4}{\rightarrow}$ such that if $\pm>$ a rise of $p_{\mathrm{N}}$ raises the expected costs of recapitalization and can not be 
an issue for the government. On the contrary, if \pm . $\frac{q}{\rightarrow}$ the government will increase $p_{N}$ since the bene..ts of a higher probability of success of rolled over projects outweights the extra-cost due to the increase of domestic currency external debt of banks. Then we de..ne a strategy labelled "accommodating forbearance" as a strategy of forbearance together with an increase in the price of the non-tradable good. Then, the condition for existence of a too many to fail is altered. If $c(m) \cdot m R^{m i n}\left(p_{N}\right)$, a too many to fail is not possible. According to Mitchell's analysis, there is no constraint on ex-ante monitoring activities. However, if (i) \pm * $\underline{\text { and }}$ (ii) $m R^{\min }\left(p_{\underline{N}}\right), c(m), m R^{\min }\left(p_{\bar{N}}\right)$, then a too many to fail is made possible by the government's capacity of lowering ex-post costs associated to a policy of forbearance through a real appreciation.

An ex-post policy of closure entails closure costs with certainty while leaving banks open results in costs of recapitalization only if the rolled over projects fails. The government's ability to prompt a real appreciation allows it to lower this cost and makes forbearance more valuable. Following Mitchell's analysis, this constraints the possibility to implement ex-ante monitoring capacity through a higher probability of facing a too many to fail. ${ }^{15} \mathrm{~N}$ ote that this situation is more likely to occur when the number of ..nancially distressed banks is high. ${ }^{16}$ The basic idea is that in A sian countries, despite of pressures on nominal exchange rates, the ongoing real appreciation has contributed to preclude governments from being able to implement an ec cient prudential policy. It may have found expression in softening non-performing loans classi..cation standards, loosening capital requirements or pursuing soft regulatory policies.

\section{Concluding remarks}

The example of A sian countries led us to investigate the ..rms' motivation to borrow in dollar. Why did they choose to contract a (hard) foreign currency debt while depreciation (or devaluation) is probable? We supply here an insurance-based explanation. Contracting a dollar denominated loan may provide ..rms with a higher probability of facing a soft budget constraint, if their investment project is poor. A noticeable consequence of this analysis is that the higher the proportion of poor projects in the economy, the more ..rms will be prone to borrow in dollar. However, ..rms' foreign currencies indebtedness goes hand in hand with a weakening of bank-

\footnotetext{
${ }^{15}$ See the appendix.

${ }^{16}$ Since for $m=0$, costs associated to both policies are 0 , and considering that $c(m)$ is convex in $m$ while $R^{\mathrm{min}}$ is linear in $m$, this statement requires the assumption that the slope of $c(m)$ in zero is lower than the one of $R^{\mathrm{min}}$.
} 
ing system while the monetary institutions might be constrained in the regulatory/ supervisory policies they are able to implement.

The situation described above may be less likely to occur if the government considered a larger objective function. First, it would take into account the weakening of the ..nancial position of sound banks (that is without non-performing loans in their portfolio) since there is an increase in the domestic currency value of their external debt. Furthermore, it will take into account the consequences of the real appreciation on the domestic tradable good sector. These consequences depend on dixerent and opposite exects if we consider a traditional model of trade (see Gandolfo, 1998; chap 6). First, a revenue exect can happen if the rise of $p_{N}$ induces an increase in domestic demand of tradable goods (and if domestic producers bene..t from this increase in the demand). Nevertheless, if we assume that producing one units of the tradable good requires a quantity $x$ of the non-tradable good, pro..tability of tradable good sector decreases. We should also note that in a setting in which labor is a general factor moving freely from sector to sector, the increase in $p_{N}$ the government prompts to cut its costs may impede a resource movement exect from the non-tradable to the tradable good sector (which may be ex-ante optimal if we solely consider the initial increase in $\mathrm{p}_{\mathrm{T}}$ ).

The approach developed in this paper could be extended to develop a dynamic analysis of intermediated foreign currency loan, for example along the lines of models developed by Dekle and K letzer (2001) or Giannetti (2000). ${ }^{17}$ These authors propose models of the A sian crisis based on a dynamic analysis of banks' incentives to roll over defaulting loans. Yet they do not consider the non-tradable good sector. It would require to take into account both ..scal considerations (since it determines the government ability to repay domestic depositors and foreign lenders), the level of foreign exchange reserves and foreign lenders behavior. It would certainly allow us to draw some interesting conclusions on the ability of the government both to prompt a real appreciation and to implement a strict prudential policy.

\section{A ppendix}

We present here a simpli..ed version of Mitchell's analysis in order to show formally that the possible occurrence of a too many to fail situation constrains the monitoring capacity the gov-

\footnotetext{
${ }^{17} \mathrm{G}$ iannetti's model does not rely on the assumption of deposit or foreign currency debt guarantee conversely to Dekle and Kletzer analysis or to the present paper.
} 
ernment can implement ex-ante (for a complete analysis, see Mitchell, (1998)). There are m banks with non-performing loans in their portfolio. The timing is as the one described above. At $\mathrm{t}=0$, the government chooses a monitoring capacity, ' 2 [0;1], and supports the cost $\mathrm{H}\left({ }^{\prime}\right)$ assumed to be convex in '. At $\mathrm{t}=1$, banks observe the price of the tradable good, assumed to be high enough to make a soft liquidation policy valuable. Then, they choose a liquidation policy with respect to defaulting loans. The government monitors banks and apply an ex-post policy to passive detected banks. At $t=2$, poor rolled over projects are realized and the government pays back foreign lenders if projects fail.

Because of the monitoring capacity, the total ex-post cost of a closure policy is $C\left({ }^{\prime} ; m\right)=$ $H\left({ }^{\prime}\right)+c\left({ }^{\prime} m\right)+\left(1 i^{\prime}\right) m R^{m i n}$, where $R^{\min }=(1 ; \quad q)\left[p_{T} i^{\circledR} D_{T}\right]$. The last term dixers from Mitchell; it is justi..ed by the fact that at the end of the game, foreign lenders must be repaid if non-terminated poor projects fail. Let suppose that (i) the bene.ts of detecting a small number of banks exceeds the costs of closing these banks and (ii) at ' $=0$, the marginal cost of monitoring does not outweight the net marginal bene.t of closing a small number of banks. Note that the expected payox of a passive banks is now $\left(1_{i}{ }^{\prime}\right) q_{T}\left(D_{T} i p_{T}\right)$; moreover, if the government apply a closure policy to passive detected banks, their payox is zero. The total cost of a recapitalization policy is $\mathrm{R}^{\prime} ; \mathrm{m}$ ) $=\mathrm{mR}^{\mathrm{min}}$ (if recapitalization is to be the optimal ex-post strategy, the government does not implement any monitoring capacity since monitoring is costly).

As Mitchell let state the following without proof. Denote by ' the value of ' $2\left[0 ;{ }^{\prime}\right]$ such that the ..rst-order condition for minimization of $C^{\prime}\left({ }^{\prime} ; m\right)$ is satis..ed. When the ..rst order condition is satis..ed

$$
\left.\mathrm{H}^{q^{\prime}}\right)+\frac{@\left({ }_{-} \mathrm{m}\right)}{@} ; \mathrm{mR}^{\mathrm{min}}=0
$$

The optimal value 'x given a policy of intervention will either be ' or ${ }_{-}^{*}$, where ${ }^{*}$ represents a corner solution ( $\leftarrow$ is high enough to make a soft liquidation policy not valuable for banks). In the latter case,

$$
\left.H^{q-}\right)>m^{\min } i \frac{@(-m)}{@}
$$

and

$$
\left.\mathrm{H}\left({ }^{\prime}\right)<\mathrm{C}^{\prime} ; \mathrm{m}\right)
$$

Consider ..rst that the government expects that no collusion between banks. B ecause of assumptions (i) and (ii), ' > 0 implies that the total ex-post costs of a closure policy are lower than 
total cost with ' $=0$. Since $C(0 ; m)$ is equal to $R(0 ; m)$, the total cost of a closure policy must be lower than the total cost of a recapitalization policy. Then there exists an equilibrium with ' $>0$ and closure of passive detected banks (we do not address the case in which accommodating forbearance is the preferred strategy ex-ante because of real appreciation).

A ssume that the government wants to implement a high monitoring capacity (the corner solution). A too many to fail occurs if the ex-post costs of closure are higher than ex-post costs of recapitalization, that is if

$$
\mathrm{c}\left({ }^{\prime} \mathrm{m}\right)+\left(1 \mathrm{i}^{-}\right) \mathrm{mR}^{\mathrm{min}}, \mathrm{mR}^{\min }
$$

or equivalently,

$$
\frac{\mathrm{c}(-\mathrm{m})}{\perp}, \mathrm{R}^{\mathrm{min}}
$$

Suppose that this condition is satis..ed, because of induced -valuable- real appreciation and that the government expects that such an implicit collusion may occur. Then, there exists an equilibrium with ' and closure of detected passive banks. To check this, note that since monitoring is costly

$$
H(0)+m R^{\min }<H\left(\stackrel{\leftarrow}{)}+m R^{\min }\right.
$$

where the last term stands for the costs of the government facing a too many to fail situation. From the preceding, we know that

$$
\left.H\left({ }_{-}^{\prime}\right)+C_{-}^{\prime} m\right)+\left(1 i_{-}^{\prime}\right) m^{\min }<H(0)+m R^{\min }
$$

Hence

$$
\left.\left.\mathrm{H}\left({ }_{-}^{\prime}\right)+\mathrm{C}_{-}^{\prime} \mathrm{m}\right)+\left(1_{\mathrm{i}}{ }_{-}^{\prime}\right) \mathrm{mR}^{\min }<\mathrm{H}^{(\leftarrow)}\right)+\mathrm{mR}^{\min }
$$

Then the equilibrium policy corresponds to a softening of prudential policy; the government must ..x a monitoring capacity equal to ' instead of ${ }^{-}$. 


\section{R eferences}

Berglöf, E., Roland, G., 1997. Soft Budget Constraint and Credit Crunches in Financial Transition, European E conomic R eview 41 (3-5), 807-17.

BIS, 1999. 68th Annual Report. Bank for International Settlements, Basle.

Burnside, C., E ichenbaum, M., R ebelo, S., 2001. Hedging and $F$ inancial Fragility in F ixed Exchange Rate R egimes, European Economic Review 45 (7), 1151-94.

Caballero, R. J ., K rishnamurty, A ., 2000. Dollarization of Liabilities: Underinsurance and Domestic Financial Underdevelopment, Working Paper No 7792, NBER, Cambridge, MA.

Caprio, G., Honohan, P., 1999. Restoring Banking Stability: Beyond Supervised Capital Requirements, J ournal of E conomic Perspectives 13 (4), 43-64.

Corsetti, G., Pesenti, P., Roubini, N., 1999. Paper Tigers? A M odel of the A sian Crisis, European Economic Review 43, 1211-36.

Dekle, R., K letzer, K., 2001. Domestic Bank Regulation and Financial Crises: Theory and Empirical Evidence from East Asia, NBER, Cambridge, MA.

Dewatripont, M ., M askin, E., 1995. Credit and $\mathrm{E} \phi$ ciency in Centralized and Decentralized $\mathrm{E}$ conomies, Review of Economic Studies 62 (4), 541-55.

Dewatripont, M., Roland, G., 2000. Soft Budget Constraints, Transition, and Financial Systems, J ournal of Institutional and Theoretical economics 156, 245-260.

Gandolfo, G., 1998. International Trade Theory and Policy. Springer-Verlag, Berlin.

Giannetti, M., 2000. On the Causes of Overlending: Are Guarantees on Deposits the Culprit?, SITE, Stockholm School of Economics, mimeo.

Hawkins, J., Turner, P., 1999. Bank Restructuring in Practice: An Overview. In: Bank for International Settlements. Bank Restructuring in Practice, BIS Policy Paper No 6, pp.6-105.

IMF , 1998. World Economic Outlook. International Monetary Fund, Washington D.C.

IM F , 1999. Financial Sector C risis and R estructuring: Lessons from A sia. International M onetary Fund, Washington D.C.

J eanne, O., 2000. Foreign Currency debt and the Global Financial Architecture, European Economic Review 44 (4-6), 719-27.

Kornai, J ., 1980. E conomics of Shortage. North-Holland, A msterdam.

Mailath, G. J., Mester, L. J., 1994. A Positive Analysis of Bank Closure, J ournal of Financial Intermediation 3 (3), 272-99. 
Maskin, E., Xu, C., 2001. Soft budget Constraints Theories: From Centralization to the Market, Economics of transition 9 (1), 1-27.

Mishkin, F. S., 1999. Lessons from the A sian Crisis, J ournal of International M oney and Finance $18,709-23$.

M itchell, J., 1998. Strategic Creditor Passivity, Regulation and Bank Bailouts, Discussion Paper No 1780, CEPR, London.

Schneider, M., Tornell, A., (2000), Balance Sheet Exects, B ailout Guarantees and Financial Crises. Working Paper No 8060, NBER, Cambridge, MA. 


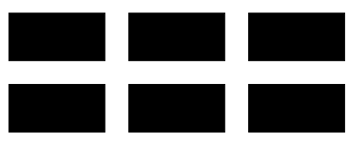

THE WILLIAM DAVIDSON INSTITUTE

AT THE UNIVERSITY OF MICHIGAN BUSINESSSCHOOL

\section{DAVIDSON INSTITUTE WORKING PAPER SERIES - Most Recent Papers}

The entire Working Paper Series is available at: www.wdi.bus.umich.edu

CURRENT AS OF $7 / 06 / 01$

\begin{tabular}{|c|c|c|}
\hline Publication & Authors & Date \\
\hline No. 380 Dollarization of Liabilities in Non-tradable Goods Sector & Frédéric Chabellard & June 2001 \\
\hline $\begin{array}{l}\text { No. } 379 \text { Lessons from the Russian Meltdown: The Economics of Soft } \\
\text { Legal Constraints }\end{array}$ & Enrico Perotti & Mar. 2001 \\
\hline No. 378 Effective Tax Rates in Transition & Vlad Ivanenko & May 2001 \\
\hline $\begin{array}{l}\text { No. } 377 \text { Some Explanations for Changes in the Distribution of } \\
\text { Household Income in Slovakia: } 1988 \text { and } 1996\end{array}$ & $\begin{array}{l}\text { Thesia Garner and Katherine } \\
\text { Terrell }\end{array}$ & May 2001 \\
\hline $\begin{array}{l}\text { No. } 376 \text { Competition and Enterprise Performance in Transition } \\
\text { Economies: Evidence from a Cross-country Survey }\end{array}$ & $\begin{array}{l}\text { Wendy Carlin, Steven Fries, } \\
\text { Mark Schaffer and Paul Seabright }\end{array}$ & May 2001 \\
\hline $\begin{array}{l}\text { No. } 375 \text { Why More is Actually Less: New Interpretations of China's } \\
\text { Labor-Intensive FDI }\end{array}$ & Yasheng Huang & May 2001 \\
\hline No. 374 Economic Fragmentation and FDI in China & Yasheng Huang & May 2001 \\
\hline $\begin{array}{l}\text { No. } 373 \text { Earnings Disparities in the Czech Republic: Evidence of the } \\
\text { Past Decade and Cross-National Comparison }\end{array}$ & Jiri Vecernik & May 2001 \\
\hline $\begin{array}{l}\text { No. } 372 \text { Economic Reform, Democracy and Growth During Post- } \\
\text { Communist Transition }\end{array}$ & Jan Fidrmuc & Mar. 2001 \\
\hline $\begin{array}{l}\text { No. } 371 \text { Do Multinational Enterprises Substitute Parent Jobs for Foreign } \\
\text { Ones? Evidence from Firm Level Panel Data }\end{array}$ & Jozef Konings and Alan Murphye & Apr. 2001 \\
\hline $\begin{array}{l}\text { No. } 370 \text { From Needs to the Market: Changing Inequality of Household } \\
\text { Income in the Czech Transition }\end{array}$ & Jiri Vecernik & Apr. 2001 \\
\hline $\begin{array}{l}\text { No. } 369 \text { Competition and Corporate Governance: Substitutes or } \\
\text { Complements? Evidence from the Warsaw Stock Exchange }\end{array}$ & $\begin{array}{l}\text { Irena Grosfeld and Thierry } \\
\text { Tressel }\end{array}$ & Mar. 2001 \\
\hline $\begin{array}{l}\text { No. } 368 \text { Multinational Corporations as Catalyst for Industrial } \\
\text { Development: The Case of Poland }\end{array}$ & $\begin{array}{l}\text { Carlo Altomonte and Laura } \\
\text { Resmini }\end{array}$ & Feb. 2001 \\
\hline No. 367 A Multi-Task Theory of the State Enterprise Reform & $\begin{array}{l}\text { Chong-En Bai, David D. Li, } \\
\text { Zhigang Tao, and Yijiang Wang }\end{array}$ & Mar. 2001 \\
\hline No. 366a Confidence Building in Emerging Stock Markets & Enrico C. Perotti and Luc Laeven & June 2001 \\
\hline No. 366 Confidence Building in Emerging Stock Markets & $\begin{array}{l}\text { Enrico C. Perotti, Luc Laeven, } \\
\text { and Pieter van Oijen }\end{array}$ & Dec. 2000 \\
\hline $\begin{array}{l}\text { No. } 365 \text { Incentive Contracting versus Ownership Reforms: Evidence } \\
\text { from China's Township and Village Enterprises }\end{array}$ & $\begin{array}{l}\text { Chun Chang, Brian McCall, and } \\
\text { Yijang Wang }\end{array}$ & Nov. 2000 \\
\hline $\begin{array}{l}\text { No. } 364 \text { Individual Pay and Outside Options: Evidence from the Polish } \\
\text { Labour Force Survey }\end{array}$ & $\begin{array}{l}\text { Fiona Duffy and Patrick Paul } \\
\text { Walsh }\end{array}$ & Mar. 2001 \\
\hline $\begin{array}{l}\text { No. } 363 \text { Investment, Credit Rationing and the Soft Budget Constraint: } \\
\text { Evidence from Czech Panel Data (revised Davidson Institute Working } \\
\text { Paper No. 60a) }\end{array}$ & Lubomír Lízal and Jan Svejnar & Feb. 2001 \\
\hline $\begin{array}{l}\text { No. } 362 \text { A Network Perspective on Inter-Organizational Transfer of } \\
\text { R\&D Capabilities: A Study of International Joint Ventures in Chinese } \\
\text { Automobile Industry }\end{array}$ & $\begin{array}{l}\text { Zheng Zhao, Jaideep Anand and } \\
\text { Will Mitchell }\end{array}$ & Feb. 2001 \\
\hline $\begin{array}{l}\text { No. } 361 \text { Network Restructuring and Firm Creation in East-Central } \\
\text { Europe: A Public-Private Venture }\end{array}$ & Gerald A. McDermott & Dec. 2000 \\
\hline $\begin{array}{l}\text { No. } 360 \text { Responses of Private and Public Schools to Voucher Funding: } \\
\text { The Czech and Hungarian Experience }\end{array}$ & $\begin{array}{l}\text { Randall K. Filer and Daniel } \\
\text { Münich }\end{array}$ & Oct. 2000 \\
\hline $\begin{array}{l}\text { No. } 359 \text { Labor Market Uncertainty and Private Sector Labor Supply in } \\
\text { Russia }\end{array}$ & Steven Stillman & Sept. 2000 \\
\hline $\begin{array}{l}\text { No. } 358 \text { Russian Roulette-Expenditure Inequality and Instability in } \\
\text { Russia, 1994-1998 }\end{array}$ & Branko Jovanovic & Sept. 2000 \\
\hline
\end{tabular}




\begin{tabular}{|c|c|c|}
\hline No. 357 Dealing with the Bad Loans of the Chinese Banks & John P. Bonin and Yiping Huang & Jan. 2001 \\
\hline No. 356 Retail Banking in Hungary: A Foreign Affair? & John P. Bonin and István Ábel & Dec. 2000 \\
\hline $\begin{array}{l}\text { No. } 355 \text { Optimal Speed of Transition: Micro Evidence from the Czech } \\
\text { Republic }\end{array}$ & $\begin{array}{l}\text { Stepan Jurajda and Katherine } \\
\text { Terrell }\end{array}$ & Dec. 2000 \\
\hline No. 354 Political Instability and Growth in Dictatorships & $\begin{array}{l}\text { Jody Overland, Kenneth L. } \\
\text { Simons and Michael Spagat }\end{array}$ & Nov. 2000 \\
\hline No. 353 Disintegration and Trade & Jarko Fidrmuc and Jan Fidrmuc & Nov. 2000 \\
\hline $\begin{array}{l}\text { No. } 352 \text { Social Capital and Entrepreneurial Performance in Russia: A } \\
\text { Panel Study }\end{array}$ & Bat Batjargal & Dec. 2000 \\
\hline $\begin{array}{l}\text { No. 351 Entrepreneurial Versatility, Resources and Firm Performance in } \\
\text { Russia: A Panel Study }\end{array}$ & Bat Batjargal & Dec. 2000 \\
\hline $\begin{array}{l}\text { No. } 350 \text { The Dynamics of Entrepreneurial Networks in a Transitional } \\
\text { Economy: The Case of Russia }\end{array}$ & Bat Batjargal & Dec. 2000 \\
\hline $\begin{array}{l}\text { No. 349a R\&D and Technology Spillovers via FDI: Innovation and } \\
\text { Absorptive Capacity }\end{array}$ & Yuko Kinoshita & Apr. 2001 \\
\hline $\begin{array}{l}\text { No. } 349 \text { R\&D and Technology Spillovers via FDI: Innovation and } \\
\text { Absorptive Capacity }\end{array}$ & Yuko Kinoshita & Nov. 2000 \\
\hline $\begin{array}{l}\text { No. } 348 \text { Microeconomic aspects of Economic Growth in Eastern } \\
\text { Europe and the Former Soviet Union, } 1950-2000\end{array}$ & Sergei Guriev and Barry W. Ickes & Nov. 2000 \\
\hline $\begin{array}{l}\text { No. } 347 \text { Effective versus Statutory Taxation: Measuring Effective Tax } \\
\text { Administration in Transition Economies }\end{array}$ & $\begin{array}{l}\text { Mark E. Schaffer and Gerard } \\
\text { Turley }\end{array}$ & Nov. 2000 \\
\hline $\begin{array}{l}\text { No. } 346 \text { Objectives and Constraints of Entrepreneurs: Evidence from } \\
\text { Small and Medium Size Enterprises in Russia and Bulgaria }\end{array}$ & $\begin{array}{l}\text { Francesca Pissarides, Miroslav } \\
\text { Singer and Jan Svejnar }\end{array}$ & Oct. 2000 \\
\hline No. 345 Corruption and Anticorruption in the Czech Republic & $\begin{array}{l}\text { Lubomír Lízal and Evžen } \\
\text { Kočenda }\end{array}$ & Oct. 2000 \\
\hline No. 344 The Effects of Direct Foreign Investment on Domestic Firms & Jozef Konings & Oct. 2000 \\
\hline No. 343 On the Identification of Relative Wage Rigidity Dynamics & Patrick A. Puhani & Oct. 2000 \\
\hline $\begin{array}{l}\text { No. } 342 \text { The Determinants of Foreign Direct Investment in Transition } \\
\text { Economies }\end{array}$ & Alan A. Bevan and Saul Estrin & Oct. 2000 \\
\hline No. 341 The Global Spread of Stock Exchanges, 1980-1998 & Klaus Weber and Gerald F. Davis & Nov. 2000 \\
\hline $\begin{array}{l}\text { No. } 340 \text { The Costs and Benefits of Euro-isation in Central-Eastern } \\
\text { Europe Before or Instead of EMU Membership }\end{array}$ & D. Mario Nuti & Oct. 2000 \\
\hline No. 339 Debt Overhang and Barter in Russia & $\begin{array}{l}\text { Sergei Guriev, Igor Makarov and } \\
\text { Mathilde Maurel }\end{array}$ & Sept. 2000 \\
\hline $\begin{array}{l}\text { No. } 338 \text { Firm Performance and the Political Economy of Corporate } \\
\text { Governance: Survey Evidence for Bulgaria, Hungary, Slovakia and } \\
\text { Slovenia }\end{array}$ & $\begin{array}{l}\text { Patrick Paul Walsh and Ciara } \\
\text { Whela }\end{array}$ & July 2000 \\
\hline No. 337 Investment and Instability & $\begin{array}{l}\text { Nauro F. Campos and Jeffrey B. } \\
\text { Nugent }\end{array}$ & May 2000 \\
\hline $\begin{array}{l}\text { No. } 336 \text { The Evolution of the Insurance Sector in Central and } \\
\text { Eastern Europe and the former Soviet Union }\end{array}$ & Robert B.K. Pye & Aug. 2000 \\
\hline $\begin{array}{l}\text { No. } 335 \text { Institutional Technology and the Chains of Trust: Capital } \\
\text { Markets and Privatization in Russia and the Czech Republic }\end{array}$ & Bruce Kogut and Andrew Spicer & Aug. 2000 \\
\hline No. 334 The Evolution of Market Integration in Russia & $\begin{array}{l}\text { Daniel Berkowitz and David N. } \\
\text { DeJong }\end{array}$ & Aug. 2000 \\
\hline No. 333 Efficiency and Market Share in Hungarian Corporate Sector & László Halpern and Gábor Körösi & July 2000 \\
\hline No. 332 Search-Money-and-Barter Models of Financial Stabilization & $\begin{array}{l}\text { S.I. Boyarchenko and S.Z. } \\
\text { Levendorskii }\end{array}$ & July 2000 \\
\hline $\begin{array}{l}\text { No. } 331 \text { Worker Training in a Restructuring Economy: Evidence from } \\
\text { the Russian Transition }\end{array}$ & $\begin{array}{l}\text { Mark C. Berger, John S. Earle } \\
\text { and Klara Z. Sabirianova }\end{array}$ & Aug. 2000 \\
\hline $\begin{array}{l}\text { No. } 330 \text { Economic Development in Palanpur 1957-1993: A Sort of } \\
\text { Growth }\end{array}$ & Peter Lanjouw & Aug. 2000 \\
\hline $\begin{array}{l}\text { No. } 329 \text { Trust, Organizational Controls, Knowledge Acquisition from } \\
\text { the Foreign Parents, and Performance in Vietnamese International Joint } \\
\text { Ventures }\end{array}$ & $\begin{array}{l}\text { Marjorie A. Lyles, Le Dang } \\
\text { Doanh, and Jeffrey Q. Barden }\end{array}$ & June 2000 \\
\hline
\end{tabular}




\begin{tabular}{|c|c|c|}
\hline $\begin{array}{l}\text { No. } 328 \text { Comparative Advertising in the Global Marketplace: The } \\
\text { Effects of Cultural Orientation on Communication }\end{array}$ & $\begin{array}{l}\text { Zeynep Gürhan-Canli and } \\
\text { Durairaj Maheswaran }\end{array}$ & Aug. 2000 \\
\hline No. 327 Post Privatization Enterprise Restructuring & Morris Bornstein & July 2000 \\
\hline No. 326 Who is Afraid of Political Instability? & $\begin{array}{l}\text { Nauro F. Campos and Jeffrey B. } \\
\text { Nugent }\end{array}$ & July 2000 \\
\hline No. 325 Business Groups, the Financial Market and Modernization & Raja Kali & June 2000 \\
\hline $\begin{array}{l}\text { No. } 324 \text { Restructuring with What Success? A Case Study of Russian } \\
\text { Firms }\end{array}$ & Susan Linz & July 2000 \\
\hline $\begin{array}{l}\text { No. } 323 \text { Priorities and Sequencing in Privatization: Theory and } \\
\text { Evidence from the Czech Republic }\end{array}$ & $\begin{array}{l}\text { Nandini Gupta, John C. Ham and } \\
\text { Jan Svejnar }\end{array}$ & May 2000 \\
\hline $\begin{array}{l}\text { No. } 322 \text { Liquidity, Volatility, and Equity Trading Costs Across } \\
\text { Countries and Over Time }\end{array}$ & $\begin{array}{l}\text { Ian Domowitz, Jack Glen and } \\
\text { Ananth Madhavan }\end{array}$ & Mar. 2000 \\
\hline $\begin{array}{l}\text { No. } 321 \text { Equilibrium Wage Arrears: A Theoretical and Empirical } \\
\text { Analysis of Institutional Lock-In }\end{array}$ & $\begin{array}{l}\text { John S. Earle and Klara Z. } \\
\text { Sabirianova }\end{array}$ & Oct. 2000 \\
\hline No. 320 Rethinking Marketing Programs for Emerging Markets & $\begin{array}{l}\text { Niraj Dawar and Amitava } \\
\text { Chattopadhyay }\end{array}$ & June 2000 \\
\hline $\begin{array}{l}\text { No. } 319 \text { Public Finance and Low Equilibria in Transition Economies: } \\
\text { the Role of Institutions }\end{array}$ & $\begin{array}{l}\text { Daniel Daianu and Radu } \\
\text { Vranceanu }\end{array}$ & June 2000 \\
\hline $\begin{array}{l}\text { No. } 318 \text { Some Econometric Evidence on the Effectiveness of Active } \\
\text { Labour Market Programmes in East Germany }\end{array}$ & $\begin{array}{l}\text { Martin Eichler and Michael } \\
\text { Lechner }\end{array}$ & June 2000 \\
\hline No. 317 A Model of Russia's "Virtual Economy" & R.E Ericson and B.W Ickes & May 2000 \\
\hline $\begin{array}{l}\text { No. } 316 \text { Financial Institutions, Financial Contagion, and Financial } \\
\text { Crises }\end{array}$ & $\begin{array}{l}\text { Haizhou Huang and Chenggang } \\
\mathrm{Xu}\end{array}$ & Mar. 2000 \\
\hline $\begin{array}{l}\text { No. } 315 \text { Privatization versus Regulation in Developing Economies: The } \\
\text { Case of West African Banks }\end{array}$ & $\begin{array}{l}\text { Jean Paul Azam, Bruno Biais, and } \\
\text { Magueye Dia }\end{array}$ & Feb. 2000 \\
\hline $\begin{array}{l}\text { No. } 314 \text { Is Life More Risky in the Open? Household Risk-Coping and } \\
\text { the Opening of China's Labor Markets }\end{array}$ & John Giles & Apr. 2000 \\
\hline $\begin{array}{l}\text { No. } 313 \text { Networks, Migration and Investment: Insiders and Outsiders in } \\
\text { Tirupur's Production Cluster }\end{array}$ & $\begin{array}{l}\text { Abhijit Banerjee and Kaivan } \\
\text { Munshi }\end{array}$ & Mar. 2000 \\
\hline $\begin{array}{l}\text { No. } 312 \text { Computational Analysis of the Impact on India of the Uruguay } \\
\text { Round and the Forthcoming WTO Trade Negotiations }\end{array}$ & $\begin{array}{l}\text { Rajesh Chadha, Drusilla K. } \\
\text { Brown, Alan V. Deardorff and } \\
\text { Robert M. Stern }\end{array}$ & Mar. 2000 \\
\hline No. 311 Subsidized Jobs for Unemployed Workers in Slovakia & Jan. C. van Ours & May 2000 \\
\hline No. 310 Determinants of Managerial Pay in the Czech Republic & $\begin{array}{l}\text { Tor Eriksson, Jaromir Gottvald } \\
\text { and Pavel Mrazek }\end{array}$ & May 2000 \\
\hline $\begin{array}{l}\text { No. } 309 \text { The Great Human Capital Reallocation: An Empirical Analysis } \\
\text { of Occupational Mobility in Transitional Russia }\end{array}$ & Klara Z. Sabirianova & Oct. 2000 \\
\hline No. 308 Economic Development, Legality, and the Transplant Effect & $\begin{array}{l}\text { Daniel Berkowitz, Katharina } \\
\text { Pistor, and Jean-Francois Richard }\end{array}$ & Feb. 2000 \\
\hline $\begin{array}{l}\text { No. } 307 \text { Community Participation, Teacher Effort, and Educational } \\
\text { Outcome: The Case of El Salvador's EDUCO Program }\end{array}$ & Yasuyuki Sawada & Nov. 1999 \\
\hline No. 306 Gender Wage Gap and Segregation in Late Transition & Stepan Jurajda & May 2000 \\
\hline $\begin{array}{l}\text { No. } 305 \text { The Gender Pay Gap in the Transition from Communism: } \\
\text { Some Empirical Evidence }\end{array}$ & Andrew Newell and Barry Reilly & May 2000 \\
\hline No. 304 Post-Unification Wage Growth in East Germany & Jennifer Hunt & Nov. 1998 \\
\hline $\begin{array}{l}\text { No. } 303 \text { How Does Privatization Affect Workers? The Case of the } \\
\text { Russian Mass Privatization Program }\end{array}$ & Elizabeth Brainerd & May 2000 \\
\hline $\begin{array}{l}\text { No. } 302 \text { Liability for Past Environmental Contamination and } \\
\text { Privatization }\end{array}$ & Dietrich Earnhart & Mar. 2000 \\
\hline No. 301 Varieties, Jobs and EU Enlargement & $\begin{array}{l}\text { Tito Boeri and Joaquim Oliveira } \\
\text { Martins }\end{array}$ & May 2000 \\
\hline No. 300 Employer Size Effects in Russia & Todd Idson & Apr. 2000 \\
\hline $\begin{array}{l}\text { No. } 299 \text { Information Complements, Substitutes, and Strategic Product } \\
\text { Design }\end{array}$ & $\begin{array}{l}\text { Geoffrey G. Parker and Marshall } \\
\text { W. Van Alstyne }\end{array}$ & Mar. 2000 \\
\hline $\begin{array}{l}\text { No. } 298 \text { Markets, Human Capital, and Inequality: Evidence from Rural } \\
\text { China }\end{array}$ & $\begin{array}{l}\text { Dwayne Benjamin, Loren Brandt, } \\
\text { Paul Glewwe, and Li Guo }\end{array}$ & May 2000 \\
\hline
\end{tabular}


The entire Working Paper Series is available at: www.wdi.bus.umich.edu

\begin{tabular}{|c|c|c|}
\hline No. 297 Corporate Governance in the Asian Financial Crisis & $\begin{array}{l}\text { Simon Johnson, Peter Boone, } \\
\text { Alasdair Breach, and Eric } \\
\text { Friedman }\end{array}$ & Nov. 1999 \\
\hline No. 296 Competition and Firm Performance: Lessons from Russia & J. David Brown and John S. Earle & Mar. 2000 \\
\hline No. 295 Wage Determination in Russia: An Econometric Investigation & $\begin{array}{l}\text { Peter J. Luke and Mark E. } \\
\text { Schaffer }\end{array}$ & Mar. 2000 \\
\hline $\begin{array}{l}\text { No. } 294 \text { Can Banks Promote Enterprise Restructuring?: Evidence From } \\
\text { a Polish Bank's Experience }\end{array}$ & John P. Bonin and Bozena Leven & Mar. 2000 \\
\hline No. 293 Why do Governments Sell Privatised Companies Abroad? & $\begin{array}{l}\text { Bernardo Bortolotti, Marcella } \\
\text { Fantini and Carlo Scarpa }\end{array}$ & Mar. 2000 \\
\hline $\begin{array}{l}\text { No. } 292 \text { Going Public in Poland: Case-by-Case Privatizations, Mass } \\
\text { Privatization and Private Sector Initial Public Offerings }\end{array}$ & Wolfgang Aussenegg & Dec. 1999 \\
\hline $\begin{array}{l}\text { No. 291a Institutional Technology and the Chains of Trust: Capital } \\
\text { Markets and Privatization in Russia and the Czech Republic }\end{array}$ & Bruce Kogut and Andrew Spicer & Feb. 2001 \\
\hline $\begin{array}{l}\text { No. } 291 \text { Institutional Technology and the Chains of Trust: Capital } \\
\text { Markets and Privatization in Russia and the Czech Republic }\end{array}$ & Bruce Kogut and Andrew Spicer & Mar. 1999 \\
\hline No. 290 Banking Crises and Bank Rescues: The Effect of Reputation & Jenny Corbett and Janet Mitchell & Jan. 2000 \\
\hline $\begin{array}{l}\text { No. } 289 \text { Do Active Labor Market Policies Help Unemployed Workers to } \\
\text { Find and Keep Regular Jobs? }\end{array}$ & Jan C. van Ours & Feb. 2000 \\
\hline No. 288 Consumption Patterns of the New Elite in Zimbabwe & Russell Belk & Feb. 2000 \\
\hline $\begin{array}{l}\text { No. } 287 \text { Barter in Transition Economies: Competing Explanations } \\
\text { Confront Ukranian Data }\end{array}$ & $\begin{array}{l}\text { Dalia Marin, Daniel Kaufmann } \\
\text { and Bogdan Gorochowskij }\end{array}$ & Jan. 2000 \\
\hline $\begin{array}{l}\text { No. } 286 \text { The Quest for Pension Reform: Poland's Security through } \\
\text { Diversity }\end{array}$ & $\begin{array}{l}\text { Marek Góra and Michael } \\
\text { Rutkowski }\end{array}$ & Jan. 2000 \\
\hline No. 285 Disorganization and Financial Collapse & $\begin{array}{l}\text { Dalia Marin and Monika } \\
\text { Schnitzer }\end{array}$ & Oct. 1999 \\
\hline No. 284 Coordinating Changes in M-form and U-form Organizations & $\begin{array}{l}\text { Yingyi Qian, Gérard Roland and } \\
\text { Chenggang Xu }\end{array}$ & May 1999 \\
\hline $\begin{array}{l}\text { No. } 283 \text { Why Russian Workers Do Not Move: Attachment of Workers } \\
\text { Through In-Kind Payments }\end{array}$ & Guido Friebel and Sergei Guriev & Oct. 1999 \\
\hline No. 282 Lessons From Fiascos in Russian Corporate Governance & $\begin{array}{l}\text { Merritt B. Fox and Michael A. } \\
\text { Heller }\end{array}$ & Oct. 1999 \\
\hline $\begin{array}{l}\text { No. } 281 \text { Income Distribution and Price Controls: Targeting a Social } \\
\text { Safety Net During Economic Transition }\end{array}$ & $\begin{array}{l}\text { Michael Alexeev and James } \\
\text { Leitzel }\end{array}$ & Mar. 1999 \\
\hline $\begin{array}{l}\text { No. 280: Starting Positions, Reform Speed, and Economic Outcomes in } \\
\text { Transitioning Economies }\end{array}$ & William Hallagan and Zhang Jun & Jan. 2000 \\
\hline No. 279 : The Value of Prominent Directors & $\begin{array}{l}\text { Yoshiro Miwa \& J. Mark } \\
\text { Ramseyer }\end{array}$ & Oct. 1999 \\
\hline No. 278: The Syste & János Kornai & Apr. 1998 \\
\hline $\begin{array}{l}\text { No. 277: The Developmental Consequences of Foreign Direct } \\
\text { Investment in the Transition from Socialism to Capitalism: The } \\
\text { Performance of Foreign Owned Firms in Hungary }\end{array}$ & Lawrence Peter King & Sept. 1999 \\
\hline $\begin{array}{l}\text { No. 276: Stability and Disorder: An Evolutionary Analysis of Russia's } \\
\text { Virtual Economy }\end{array}$ & $\begin{array}{l}\text { Clifford Gaddy and Barry W. } \\
\text { Ickes }\end{array}$ & Nov. 1999 \\
\hline $\begin{array}{l}\text { No. 275: Limiting Government Predation Through Anonymous } \\
\text { Banking: A Theory with Evidence from China. }\end{array}$ & $\begin{array}{l}\text { Chong-En Bai, David D. Li, } \\
\text { Yingyi Qian and Yijiang Wang }\end{array}$ & July 1999 \\
\hline No. 274: Transition with Labour Supply & Tito Boeri & Dec. 1999 \\
\hline $\begin{array}{l}\text { No. 273: Sectoral Restructuring and Labor Mobility: A Comparative } \\
\text { Look at the Czech Republic }\end{array}$ & Vit Sorm and Katherine Terrell & Nov. 1999 \\
\hline $\begin{array}{l}\text { No. 272: Published in: Journal of Comparative Economics "Returns to } \\
\text { Human Capital Under the Communist Wage Grid and During the } \\
\text { Transition to a Market Economy" Vol. 27, pp. 33-60 1999. }\end{array}$ & $\begin{array}{l}\text { Daniel Munich, Jan Svejnar and } \\
\text { Katherine Terrell }\end{array}$ & Oct. 1999 \\
\hline $\begin{array}{l}\text { No. 271: Barter in Russia: Liquidity Shortage Versus Lack of } \\
\text { Restructuring }\end{array}$ & $\begin{array}{l}\text { Sophie Brana and Mathilde } \\
\text { Maurel }\end{array}$ & June 1999 \\
\hline $\begin{array}{l}\text { No. 270: Tests for Efficient Financial Intermediation with Application to } \\
\text { China }\end{array}$ & Albert Park and Kaja Sehrt & Mar. 1999 \\
\hline
\end{tabular}

